Santa Clara University

Scholar Commons

Economics

Leavey School of Business

2003

\title{
Are Investments in Daughters Lower When Daughters Move Away? Evidence from Indonesia
}

Michael Kevane

SantaClara University, mkevane@scu.edu

David Levine

Follow this and additional works at: http://scholarcommons.scu.edu/econ

Part of the Economics Commons, and the Feminist, Gender, and Sexuality Studies Commons

\section{Recommended Citation}

Kevane, Michael and Levine, David I. Ian, Are Investments in Daughters Lower When Daughters Move Away? Evidence from Indonesia. World Development, Vol. 31, No. 6, 2003. Available at SSRN: http://ssrn.com/abstract=1096255 


\title{
Are Investments in Daughters Lower When Daughters Move Away?
}

\section{Evidence from Indonesia}

\author{
David Levine \\ Haas School of Business \\ University of California \\ Berkeley, CA 94720 \\ levine@haas.berkeley.edu \\ Michael Kevane \\ Department of Economics \\ Santa Clara University \\ Santa Clara, CA 95053 \\ mkevane@scu.edu
}

February 25, 2002

\begin{abstract}
In much of the developing world daughters receive lower education and other investments than do their brothers, and may even be so devalued as to suffer differential mortality. Daughter disadvantage may be due in part to social norms that prescribe that daughters move away from their natal family upon marriage, a practice known as virilocality. We evaluate the effects of virilocality on female disadvantage using data from the Indonesia Family Life Survey. We find little support for the hypothesis. There is no evidence that the overall pattern of rough equality in the treatment of boys and girls in Indonesia masks differences according to post-marital residential practice. Virilocal groups do not have "missing daughters." Nor is there other evidence of son preference, such as in relatively low height-for-age or education for girls and women in virilocal areas. Explanations of daughter disadvantage as due to virilocality should be subject to further scrutiny and contextualization.
\end{abstract}

Keywords: Virilocality, marriage, son preference, Asia, Indonesia 


\section{Introduction}

In much of the developing world girls receive less nutrition and health care, and fewer years of education, than do boys. One hypothesis for this differential treatment is that daughters often move near their in-laws after they marry- a practice known as "virilocality". If parents understand and expect to follow virilocal rules, so their daughters will leave to live in other villages, their private return to investments in their daughters' health or education might be expected to be lower than their private return in investments in their sons. Although transfers to the young woman's family at the time of marriage, old age transfers from distant daughters, altruism that parents feel toward their daughters, and many other forces may partly equalize investments, it is easy to believe that these mechanisms might not fully overcome the disincentive to invest generated by a norm of virilocality.

There is considerable anecdotal evidence suggesting that virilocality is important. A vivid, if somewhat tragic, aphorism from a virilocal region in India is well-known: "Educating daughters is like planting seeds in a neighbor's field." The World Bank, in its Voices of the Poor volume of interviews, reports a number of comments reflecting this view (Naraya 2000: 209-10): "Families are dissuaded from educating girls and young women in some countries due to marriage systems that place the daughter in the care of the husband's family after marriage. This causes parents to see female education as a waste of money since it is like investing in someone else's family (Togo 1996; Nigeria 1997).... As this is explained in Pakistan, "Daughters are destined to be 'other people's property"” (Pakistan 1996).... It is wasting money to educate girls because they will marry and join another family. -South Africa 1998."

Anthropologists, demographers, and economists have also referred to virilocality as a central cause of daughters' disadvantage relative to sons, and women's lack of well-being, power and status compared with men. Dyson and Moore (1983: 44) suggest that in northern India, "Because women are out-marriers, parents can expect little help from their daughters after marriage, whereas sons will remain 
at home." Garg and Morduch (1998, p. 473) suggest that in Ghana women are more likely to move away, and marriage markets do not work perfectly to compensate investments in daughters, and so, "the full return to investing in sons is more likely to be reaped by parents than the return to investments in daughters."1

There has, however, been very little empirical work testing the link between virilocality and female disadvantage. For India, much remains to be done in terms of testing whether virilocality in the north is responsible for son preference. The common assumption is that northern India is strongly virilocal while southern India is not. Libbee and Sopher's (1975) work cast some doubt on the virilocality hypothesis as central to the large differences in son preference typically found when comparing north and south. They found that for India (1975, p. 356) "local exogamy and the fetching of brides from some distance seem to be more widely practised throughout India than is generally acknowledged in the literature, although by no means as universally in the north as is supposed." Jeffery, Jeffery and Lyon (1988) conduct a detailed micro-study of marriage patterns, and note the remarkable variation in terms of distance traveled by brides, for even a relatively small northern town. Some of that variation is accounted for by differences between Hindus and Muslims, some by differences along class lines, and some by differences among Hindu castes. They also note that Muslims, where brides travel relatively shorter distances, nevertheless have practices that might be correlated with less female autonomy.

This paper examines the virilocality hypothesis using data from Indonesia. Indonesia is a good place to study the virilocality hypothesis because there is considerable variation in post-marriage residence. Some Indonesian ethnic groups practice virilocality, while others are ambilocal (residence with either set of parents), uxorilocal (residence with bride's family), and neolocal (residence with neither

\footnotetext{
${ }^{1}$ Other authors note the connection between virilocality and female disadvantage, but ascribe disadvantage to the migration per se rather than lower investment. Bloom, Wypij, and Das Gupta (2001, p. 68), observe that in northern India, "women are transferred between patrilines at the time of marriage and live with affinal [that is, husband's] kin... any material good that is given to a daughter belongs, in effect, to her affinal kin after marriage. This organization of the kinship structure around property, ownership, and rights ultimately marginalizes daughters in north Indian society." Skinner(1997, p. 59) emphasizes the effects of the migration: "in the East and South Asian societies where marriage is exogamous, the bride moves not only to the groom's family but to another village or town altogether, where she has no connections and her social knowledge is no longer of use." Virilocality also
} 
set of parents). ${ }^{2}$ There is also a substantial anthropological literature finding evidence of variation in the status of girls and women in Southeast Asia, although there is little evidence of the very strong son preference observed in parts of India and China (Atkinson and Errington 1990; Barnes 1980; Blackwood 1997; Errington 1990; Karim 1995; Stoler 1977; Wazir-Jahan Begum 1995). Some of this anthropological literature links the differential treatment of girls and boys to the virilocality hypothesis. To take one example, Ihromi (1994) notes that in Indonesia, among the Toba Batak, traditions were such that, "Daughters are married off to members of other lineages... Because their welfare is the responsibility of the men of those lineages, daughters do not inherit valuable goods." Ihromi then implies that investments in daughters were reduced for this reason.

In considering the narrow question of whether variation in treatment of daughters is correlated with variation in rules of post-marital residence, we take as given that causation is from the rule (virilocality) to the practice (differential treatment of daughters). The alternative, that places where parents do not invest in daughters are places where girls are easily married off to far-away places, is plausible. But this alternative does not seem to accord well with the findings of anthropologists that virilocality is indeed more like a social rule than simply an aggregate outcome of independent decisions.

Our central finding is that virilocality does not influence investments in daughters in Indonesia. This finding highlights the importance of more careful empirical work when making big-picture comparisons explaining son preference and daughter disadvantage across large regions, or when explaining son preference in India or China.

The paper proceeds as follows. Section 2 briefly reviews the theory of why virilocality might matter in making investments in daughters, and discusses circumstances when virilocality might not matter. We then discuss the econometric methods used to test the hypothesis. Section 3 introduces the dataset used in the paper and summarizes the data on post-marital rules of residence, showing a strong

features in Dube's (1997) excellent comparative analysis of gender relations between South Asia and South-east Asia.

2 The terms virilocal and uxorilocal were coined by Adam (1947). 
correlation between norms of residence and actual behavior. Section 4 presents the results of tests of whether investments in girls are lower in virilocal areas or virilocal marriages. Section 5 offers some concluding comments.

\section{Virilocality and investments in daughters}

Whether virilocality affects investments in daughters depends, of course, on the lifetime pattern of interactions between parents and their children. Two key moments in that interaction are especially relevant: marriage of the daughter and retirement (or reduction in earnings with aging) of the parents. Implicit in the hypothesis of virilocality leading to daughter disadvantage is the assumption that parents are not reimbursed by the groom or his family for parental investments in daughters. That is, parents who invest in their daughter create a positive externality in a virilocal society, but the externality need not reduce investment in daughters if the groom or his family can make a side payment that leads the wife's family to internalize the externality. Also implicit in the virilocality and daughter disadvantage hypothesis is the assumption that parents receive less in transfers from daughters as opposed to sons, especially during their old age when they have retired from work or are incapable of continuing to work. ${ }^{3}$ If daughters are expected to take in parents and care for them, even if the daughters have moved away, then there will still be incentives to invest in the daughters' future productivity.

We illustrate these points in a simple model of parents choosing how much to invest in their only daughter. To simplify the model as much as possible, we consider a static model (ignoring the actual lifecycle pattern of investments and transfers); we ignore bargaining within the family. Parents choose lifetime consumption $C$ and investment in their daughter $I$ to maximize lifetime utility from own consumption $U(C)$ and the parents' valuation of their daughter's return from the investment $V(I)$, or

3 It may also be the case that expected transfers from daughters who marry far away are particularly valuable to their parents, as weather shocks in the daughter's new village may not be highly correlated with those of her parents' village. In this case, parents continue to have incentives to invest in daughters. Rosenzweig and Stark (1989) test the force of this assumption using a village-level dataset from the Semi-arid Tropic regions of India. While the data indicate that some insurance element seems to be present in marriage, the levels of transfers associated with this insurance are very small. The importance of this motivation in determining marriage would see 


$$
U(C)+V(I)
$$

We assume the $V($.) function incorporates how higher investments in daughters raises her productivity and household income and perhaps bargaining power in her married household, netting out any resulting increase in transfers to the parents, which lowers her consumption.

Parents operate subject to the budget constraint that their own earnings $Y$, bridewealth $b$, and transfers from their daughter $t$ must equal $C+I$ :

$$
Y+b+t=C+I
$$

The transfers from the groom or his family to the parents at the time of marriage (bridewealth, $b$ ) and from the daughter back to her family would presumably be increasing in investment in daughters, but also depend on how far the daughter moves away. Let the parameter $v$ capture both the daughter's expected distance from her parents if she moves away and the probability of her moving away after marriage. This parameter measures the strength of the norm of virilocality. We then have, $b=b(I, v)$ and $t=t(I, v)$, where bridewealth increases in investments because high-investment daughters are more valuable to their future husbands and in-laws, so $b_{I}>0 .^{4}$ Likewise, $\mathrm{t}_{I}>0$. Substituting in the budget constraint gives the parents' maximand with respect to $I$ :

$$
U(Y+b+t-I)+V(I)
$$

The first order condition with respect to investment is:

$$
U^{\prime} \cdot\left(b_{I}+t_{I}-1\right)+V_{I}=0 .
$$

At the optimal level of investment, the marginal reduction in utility from investing in the daughter rather than consuming must be matched by the marginal utility of additional transfers and higher welfare from the daughter's well-being.

even less important in Indonesia, which generally has higher levels of rainfall and less micro-variation in climate shocks.

${ }^{4}$ This assumption may not hold if daughters are normatively expected to marry men with at least as high of investments, such as education. In that setting, high education of a daughter may restrict the number of eligible husbands, and lead to high dowries (in our model, large negative bridewealth). 
The key comparative static of interest for this paper is the responsiveness of investment to daughters moving further away (an increase in the virilocality parameter $v$ ). This effect is giving by the following expression:

$$
d I / d v=\left[U_{Y Y}\left(b_{I}+t_{I}-1\right)\left(b_{v}+t_{v}\right)+U_{Y}\left(b_{I v}+t_{I v}\right)\right] /\left[-U_{Y Y}\left(b_{I}+t_{I}-1\right)^{2}-U_{Y}\left(b_{I I}+t_{I I}\right)-V_{I I}\right]
$$

The second-order condition ensures the denominator is positive. Thus, the sign for the expression depends on the sign of the numerator. There is no a priori reason for this to be positive or negative; this an obvious point sometimes overlooked in the literature. For example, we might think that virilocality is associated with higher bridewealth but lower transfers, so $b_{v}>0$ and $\mathrm{t}_{I}<0$. But there is no reason to think that one is larger in magnitude than the other, and so the sign of the term is ambiguous. Two other key terms in the numerator are $b_{I v}$ and $t_{I v}$, which indicate how the returns to investments (in the form of bridewealth and transfers) change with virilocality. The returns to parents from investing in daughters who move far away may be higher or lower as the distance increases. If the groom's family will receive a higher share of the daughters' productivity in virilocal regions, then the groom's family will pay a higher transfer for a more productive daughter-in-law, and $b_{I v}>0$. Working in the other direction, if distance makes the investments in daughters less useful (because less applicable to the new local environment), then $b_{I v}<0$. In a multi-period model with uncertainty, a reduction in the size of transfers when the daughter is distant may be partially offset by the fact that such transfers may be less correlated with parental income; thus, dispersing children geographically can increase a family's diversification and improve expected well-being (Rosenzweig and Wolpin 1985).

We might easily adjust the model to include the simultaneous decision of investments in sons, but no special insight is gained. The point is that theory does not give us any compelling reasons to think that virilocality will be associated with lower investments in daughters. The matter is an empirical one. Thus, our econometric tests of the virilocality hypothesis on investment focus on the differences between sons and daughters in terms of investments, education and expenditure shares on child-oriented goods. We estimate the reduced form equation:

$$
I=\hat{a}_{0}+\hat{a}_{1} \cdot v+\hat{a}_{2} \cdot v \cdot f e m a l e+\hat{a}_{3} \cdot \boldsymbol{X}+\hat{a}_{4} \cdot \boldsymbol{Z}+\stackrel{\circ}{a}
$$


where $I$ is the level of investment in or expenditures on a child or children, $\boldsymbol{X}$ is a vector of child-level and household-level variables (such as birth order, gender, sibling size and composition), $\boldsymbol{Z}$ is a vector of variables controlling for regional characteristics that might affect incentives to invest in daughters as opposed to sons, and $v$ is a dummy variable taking on value one for virilocal regions. Our main interest is in testing whether the coefficient $\hat{a}_{2}$ is negative; that is, whether daughters are treated less favorably than sons in virilocal regions.

This test of whether girls are relatively disadvantaged in virilocal areas cannot distinguish the possibility that some other, unobserved aspect of the local economic environment, correlated with postmarital residence patters, is responsible for disadvantage. By the same token, finding that there is no disadvantage associated with virilocality cannot rule out that there is some unobserved, correlated variable that cancels the incentive to underinvest in virilocal areas (e.g., marriage payments, old age transfers from daughters to parents, or higher market returns to investments in daughters). In the regression analysis, we control for as some regional characteristics, but some always remain omitted.

One important issue is the appropriate region to include as a control for variables correlated with virilocality. The virilocality hypothesis assumes that parents have an expectation during the time of childhood of the daughter about whether the daughter will move away when she is married. This expectation need not actually come to pass; circumstances may dictate that the daughter marries close by her parents when the norm calls for her to marry far away. The relevant variable determining investment in the child is the likelihood that she will move away, not whether she moves or not in practice. Of course, her actual behavior may turn out to be a good proxy for the expectation her parents had of whether she was likely to move or not. So the relevant regional characteristics are those of the person when the person was a child. 


\section{The Indonesia Family Life Survey and virilocality}

The data used in this analysis come from the 1993 and 1997 waves of the Indonesia Family Life Survey (IFLS). The 1993 survey has information on individuals in 7224 households distributed in 321 communities; the 1997 re-survey was able to track almost all of these original households (Frankenberg and others 1995; Thomas and others 1999). The IFLS is a representative sample of 13 of 27 provinces in the country; these provinces contained 83 percent of the population in late 1993. Small provinces and the politically unstable provinces of Aceh, Irian Jaya and the former East Timor were not sampled. After stratifying by urban and rural areas, households were randomly selected in the community, either villages or neighborhoods or census tracts. Within households different members were interviewed according to various selection criteria; for example, to ensure adequate numbers of older respondents.

We use a number of different sources to identify virilocal regions. One source is a unique survey of adat, the local norms and traditional law that applied in each village. This survey, part of the 1997 IFLS, asked one respected elder in each of 270 enumeration areas about local adat. These traditional laws and local norms stand in contrast to the formal laws of the nation-state (Warren 1995). In many parts of Indonesia the state is far removed, and adat norms guide behavior. The adat questionnaire included approximately ninety questions related to customs concerning family life and gender. Each respondent was asked to state whether the custom held in traditional law and whether it was common practice at the time of the 1997 interview.

The adat survey contained a small component for determining the residential location of new conjugal units, a basic aspect of local family systems. Experts were asked, "Putting aside economic constraints, where does the newly married couple live after the wedding?" If the expert indicated that the couple would live in the parents' house, they were asked for how long. If the expert indicated that they would reside in the parents' 'place', or in a new 'place', they were asked whether this 'place' was with the male's or female's parents or relatives. We coded answers to these questions as follows. First, we coded the adat as ambilocal if the expert indicated one of the following: the new couple resided 
"wherever they want"; if they resided in "a new place for the couple;" if they resided in the parents' place but not 'with' anyone; if the couple resided with relatives after the wedding but then went on their own later; or if the expert gave multiple responses (i.e. could live with relatives or parents of either male or female). Second, we coded as an area as virilocal if the expert indicated that after the wedding the couple lived in the male's parents' house or in the male's place, and then continued to live with the male's parents or relatives, or if the couple started off in the male's place and did not move into their own place until they had a house, child, or work. Third, we coded the adat as uxorilocal if the expert indicated that after the wedding the couple lived in the female's parents' house or in the female's place, and then continued to live with the female's parents or relatives, or if the couple started off in the female's place and did not move into their own place until they had a house, child, or work. Of the 270 communities, $53 \%$ were described as traditionally uxorilocal, $23 \%$ virilocal, and 23\% ambilocal. Thirty-two localities were reported as 'switching' from uxorilocal or virilocal to ambilocal, five switched from ambilocal to uxorilocal, and only one from ambilocal to virilocal.

Table 1 shows that the adat assessment of local traditions corresponds well with individual responses to whether and where a person had moved at marriage. According to the individual responses from the 1997 survey, in adat areas that were labeled virilocal, about $68 \%$ of women married after 1970 said that their marriage was virilocal, more than three times the rate of uxorilocal marriages. Similar results hold for the responses offered by men, or using the data from the 1993 round, or using answers to questions asked in separate interviews about migration patterns.

When we cross-tabulate norms of post-marriage relocation and ethnicity, we find the expected patterns. ${ }^{5}$ As seen in Table A1 in the appendix, Balinese, Batak and Sasak reported 91, 58 and 76 percent of marriages as virilocal, respectively. In contrast, the Bugis, Javanese and Sundanese, Madura, Minang,

5 We code ethnicity using a common method for the IFLS, which is to use the language of interview if not in Indonesian. Smaller language groups are coded into larger groups according to the classifications in LeBar (1972). Hindus living in Bali are coded as Balinese. Christians living in North Sumatra are counted as Batak. We have then gone through the dataset and applied the ethnicity codings to siblings and biological children of anyone coded. These codings correspond very well with adat experts' responses concerning dominant ethnic groups of the enumeration area. 
and Banjar were predominantly uxorilocal and ambilocal (though more mixed than the virilocal groups). We also report the relevant anthropological understanding of residence patterns from LeBar's (1975) comprehensive compilation.

Javanese (who made up almost half the sample) were the most difficult to categorize.

Ethnographies emphasize the ambilocal nature of Javanese norms, with a modest tendency to locate near the wife's family (e.g., Jones, 1992). In contrast, one third of the Javanese adat experts claimed their locality was virilocal. Actual marriages in these Javanese areas were also more likely to be virilocal than in other parts of Java, though virilocal marriages still constituted less than $50 \%$ of marriages. The virilocal marriages among Javanese were more concentrated in central Java, ambilocal more common in Yogjakarta, and uxorilocal concentrated in East and Central Java.

Virilocal or uxorilocal norms mean more, presumably, when movement of sons or daughters is further away. About two-thirds of women who move at marriage move out of their villages. The IFLS also asks whether the new location is a different district or administrative unit (kecamatan and kabupatan). Between one-third and one quarter of those moving cross sub-district and district lines when they move. Women in virilocal marriages are somewhat more likely to cross district lines than men in uxorilocal marriages. Other measures, such as how often a person interacted with siblings, showed patterns consistent with virilocality and uxorilocality, implying greater social distance for women and men, respectively.

Virilocal, uxorilocal and ambilocal population groups exhibited some differences in socioeconomic indicators (restricting the sample of adults to men and women who were married at least once). Because the Balinese are both virilocal and Hindu, virilocal enumeration areas are less likely to be Muslim. Education for both adults and children are basically the same in virilocal, uxorilocal and ambilocal areas (confirmed in the regression analyses below), but there were differences in the education attainment of the parents of the adults in the sample. For these 'grandparents', education was lower in virilocal areas (much more so for 'grandmothers'), though the gap disappears for 'grandfathers' of younger respondents. Households in virilocal areas tended to have similar value of household assets and 
annual expenditures as did residents in other areas. People in virilocal societies had more siblings; family sizes average about half a child larger.

Using the data on individuals living in virilocal areas, we also find that women in virilocal areas are slightly less likely to be heads of households (and hence perhaps less likely to be divorced). This brings up one problem with using information on actual marriage patterns, or normative marriage patterns from the adat, as indicative of a rule influencing behavior. Perhaps the rule is or has been of little import because marriages in Indonesia may not be expected to last very long. A daughter who moves away, but is highly likely to return after a quick divorce, would not be subject to the investment externality. Guest (1992) reports on World Fertility Survey data from 1976, and finds the incidence of divorce to be quite high in Indonesia, with $28 \%$ of marriages ending in divorce within the first five years. ${ }^{6}$ Divorce is far less frequent in the more recent IFLS sample, with less than $10 \%$ of women indicating having been divorced. This evidence is in accord with other evidence of rapidly declining divorce rates in Indonesia (Jones 1994).

Ideally we want to know the norm of marriage residence that applied to the person when the person was a child. But a small fraction of the IFLS respondents moved from their childhood homes. If a person's parents moved when the child was under age twelve (about $2.7 \%$ of the sample), then the ethnicity of the parents might not be a good guide to what norm guided their behavior. The individual's parents might have adapted to new customs. These individuals we exclude from the analysis. Another larger group of respondents moved to a new island in the archipelago after childhood (about 7\% of the sample), that is, after age twelve when the investment by their parents in schooling had been substantially completed. For these, if the person's individual ethnicity could be coded, and if their ethnic group had a well-defined norm, we assigned to them the 'locality norm' of their ethnic group rather than the norm of their present residence. Otherwise they were excluded from the sample. We recognize there is some possibility of sample selection bias. We simply have no feasible way of knowing which norm, between 
two competing norms (that of the parents or that of the new locality), might have influenced the investment decisions of the parents. Nor can we control for the sample selection, since for adults we have little information on the determinants of their parents to migrate when the present adults were children.

\section{Are there lower investments in daughters in virilocal areas?}

We now proceed to examine the extent to which virilocality predicts low investments in daughters. We start with the relation of virilocal adat and other norms that disadvantage daughters, as reported by the adat experts. We then consider birth spacing and other measures of son preference. Following that we examine investments in early nutrition and health by looking at height-for-age, and investments in education. We close by examining buying patterns of food versus adult goods; having more daughters in virilocal areas should increase expenditures on adult goods such as tobacco if daughters are less valued.

\section{Virilocal adat and other norms}

A number of authorities provide examples from different parts of Asia where virilocal norms are part of a network of norms that reduce the status of women (Agarwal 1994; Dube 1997). Most obviously, if inheritances are partly a reward for caring for elderly parents, then parents have lower incentives to provide inheritances to distant daughters (and daughters have a difficult time claiming any inheritance their parents would like them to have). More generally, if virilocality is part of a system of patriarchy, then it will also predict women marry young relative to their husbands, women make fewer decisions in the household, and women inherit less.

We check the correspondence between virilocality and gendering of household and social relations, using the responses given by the adat experts. ${ }^{7}$ While the experts are not a random sample, they are people that one might want to ask about norms; their answers are meaningful in the same way that polling 270 anthropologists might be meaningful: subject to bias, but informative. In this case, the

6Guest (1992) finds that divorce rates vary predictably with age at marriage (more divorce) and education (less divorce), and have been declining across cohorts. Ethnicity apparently is a major element after controlling for these other factors: Sundanese have much higher divorce rates and Balinese much lower.

7 The complete analysis of responses from the adat survey are available from the authors upon request. 
answers are very interesting. Virilocality is correlated with some gendered social outcomes, but often these are the opposite of what one might expect. Consider the first category of responses concerning marriage norms. In virilocal areas women are less likely to marry when they are very young. It is less likely that women have no say in their marriage partner. There is a lower likelihood of a large disparity in age between groom and bride. A man is less likely to have multiple wives. There is more likelihood of bridewealth, but also more likelihood of dowry (i.e., more flows in both directions). On other dimensions the correlates, as given by the adat experts, of virilocality are mixed. For intra-household relations, women seem to fare slightly better in virilocal areas. After marriages end, however, they fare worse (in terms of what happens to assets of the couple). Children remain with the father in virilocal areas.

Table 2 considers the answers given by adat experts regarding norms that disadvantage daughters. Compared to uxorilocal regions, the adat experts in the virilocal regions were more likely to claim traditional norms emphasized preferring a son as first child (.60 vs. .47), and were also more likely to have no pressure to also have a daughter (.88 vs. .70). (When an adat expert indicated that there was social pressure to have a son, an answer coded 0 almost always meant no pressure to have either gender, rather than pressure to have a daughter.) These preferences presumably were related to the fact that in 48 percent of the uxorilocal regions, but only 12 percent of the virilocal ones, parents traditionally lived with their daughters. ${ }^{8}$ Correspondingly, daughters were far less likely to get the same share of inheritance as their brothers in virilocal regions (13 percent vs. 35 percent). More directly related to the issue of disadvantage, boys were far more likely to be given education priority in the uxorilocal regions (59 percent) than in the virilocal regions (30 percent). This result strongly contradicts the view that virilocality is bad for daughters. More consistent with that story, boys and girls usually received equal priority in health care, but almost none of the exceptions were in uxorilocal regions.

8 Cameron (2000), finds that there is no actual gender patterns in the residency decisions of adults over age 60 , suing the IFLS sample 
While there is more son preference in virilocal areas (in terms of wanting to have sons, and giving them better health care), the magnitude of the son preference is not strikingly high in any of the areas. Other incentives against daughters are present: according to the adat experts, in virilocal areas elderly parents are less likely to live with daughters, and sons definitely inherit more than daughters. On the other hand, sons seem to receive less education. The adat data tells us, then, that the hypothesis that there may be more son preference in virilocal areas cannot be immediately rejected.

\section{Fertility and mortality behavior indicating son preference}

Tables 3 to 6 give the results for five standard tests of son preference. In general we find few significant differences between the virilocal, uxorilocal and ambilocal areas (as defined by the adat experts). The tests are carried out using samples of different cohorts constructed from two sources, the responses of ever-married women, and the responses by adult household heads and spouses about their own siblings (i.e., their families when they were children). The data for the 1940-60 cohorts are from the adult responses, while the 1970-90 cohorts are from the ever-married women responses. Further details on the samples can be found in Kevane and Levine (2001).

If girls receive lower investments in health and nutrition in virilocal regions, then there should be a problem of "missing girls" as in much of South and East Asia (Bardhan and Klasen 1999). Table 3 breaks down the percent of children alive at particular times who are boys, according to whether the parents of the children are currently living in virilocal or uxorilocal areas. Thus, the theory of virilocal disadvantage for girls predicts a majority of children under five will be male. In fact, there are always very close to as many boys as girls, and the small deviations from equality show no pattern of preference for boys in virilocal regions. Table 3 presents the percent of children who died who were boys. As can be seen, there are no significant differences for the two areas in the different years that are meaningful for the virilocality hypothesis. Three of the four cases of statistically significant difference have more deaths of boys in virilocal and ambilocal areas, the opposite of what one might expect. 
Son preference also implies particular 'stopping patterns' as families make fertility decisions. Table 4 breaks down by locality the percent of last children who are sons, for families that have completed their fertility. Son preference implies that fertility will be completed, on average, more often following the birth of a son. There are no statistically significant differences from equality using the adat breakdown.

The theory of son preference also suggests that families of girls should be larger, on average, as parents who have daughters continue to have children in hope of producing their desired number of sons. In fact, family sizes are almost identical for boys and for girls (Table 5).

Finally, son preference implies that time intervals following birth of a daughter are shorter in length than intervals after the birth of a son, as parents hurry to have the desired son. Again, while two results have statistically significant differences from equality in Table 6, one shows longer and the other shows shorter intervals after daughters in virilocal regions.

In summary, for five tests of son preference, as expressed in mortality rates, sex composition of fertility patterns, and birth spacing, there is no evidence of son preference being stronger in virilocal regions.

\section{Investments in health and education indicating son preference}

In another test of the virilocality hypothesis, we estimate standard regressions trying to explain variation in two major investments parents make in their children: height and education. For children under age 10 we measure height as a standardized z-score using the NCHS-WHO standard height-for-age. We test whether z-scores are lower in virilocal areas. For adults, we expect a gap between male and female adult height; our tests involve checking whether this gap is larger in virilocal regions. A second indicator of investment in children is years of schooling.

Table 7 reports the results from regressions with height z-score and education attainment as dependent variables. The regressions do a credible job in explaining the cross-sectional variation. As expected, urban residents fare quite a bit better on both height and schooling indicators. It can also be 
seen that non-Muslim Indonesians were comparatively privileged in the past; both their height and education levels were higher. There is also an interesting contrast between the younger and older cohorts in the correlation of sibling size with investment outcomes. For the older cohort, number of siblings is positively correlated with nutrition and education outcomes. Presumably more surviving siblings is correlated with wealth, and hence better outcomes. For the younger cohort greater number of siblings is negatively correlated with outcomes, perhaps reflecting a tightening of family budget constraints as children survive childhood due to improvements in medical interventions and public health.

There are four explanatory variables of primary interest. The first two are interaction terms that measure being a girl or women and living in a virilocal region as opposed to an uxorilocal area (where girls might be expected to be favored). The second two are interaction terms that measure being a girl or woman, and having more siblings who are boys in virilocal areas. In areas of strong son preference, having many boy siblings might be very disadvantageous for girls. As can be seen, virilocality does not seem to matter for girls relative to boys, for nutrition and education investments. For these four variables in the four separate regressions, only one of the coefficients is statistically significant, and none of the Ftests for differences between girls or women in virilocal areas as opposed to uxorilocal areas is significant.

\section{Expenditure Shares}

Another common test of son preference is to see whether consumption shares on items largely benefiting children are higher when a larger number of children are male, and whether consumption shares on items largely intended for adults are lower when a larger number of children are male. Intuitively, parents with strong son preference who have many daughters will spend more on tobacco and adult clothing and less on children's clothing or milk than parents of many sons. ${ }^{9}$ Our test uses a standard Engel curve, where child-oriented goods are basic foodstuffs. Goods benefiting adults are coffee and tea, tobacco products

9 It should be noted that although the intuition of this test is sensible, even places where other evidence suggests very strong son preference exists, such as Bangladesh, sometimes do not exhibit son preference based on 
and betel, alcohol, ceremonies, and sweepstakes. We control for the log of expenditure, number of adults in the household, and the age and sex composition of the household. We include variables on whether the household is in a virilocal or uxorilocal area (with ambilocal the excluded category). We also include an index of prices from 1993, which captures spatial variation development and market integration across enumeration areas. Our sample is all families with at least one child 14 or younger living at home.

Our key variables are number of young daughters in the various age categories, and the interaction of daughters with virilocal and with uxorilocal traditions and/or practice. We estimate two equations, one using levels of expenditures and control variables (for both 1993 and 1997), and the other using the differences between 1993 and 1997 (that then controls for household heterogeneity).

The results are seen in Table 8. Columns 1-4 report the results from the cross-sectional regressions for the two periods; in columns 5 and 6 the explanatory variables are measured as the change in the variable from 1993 to 1997 . The results are easy to summarize. First, the proportion of children who are daughters has no relation with the share of expenditures on adult goods or food. Of more relevance for this article, when we compare virilocal and uxorilocal regions, the presence of more daughters continues to have no relation with the share of expenditures on adult goods or on food expenditures. The coefficients on the other variables are reasonable and in accord with intuition: when there are more young children, food is a greater share of expenditures; when there are adult men, adult goods are a greater share; when there are adult women, food is a greater share; when expenditures are higher, the food share is lower; female-headed household spend relatively more on food and less on adult goods; and rural areas see households spend greater shares on adult goods.

\section{Summary}

Our results find little evidence of son preference in virilocal areas, and are thus consistent with other evidence of no systematic son preference in Indonesia on average (Kevane and Levine, 2001). We did perform extensive checks to make sure our results were robust to changing definitions or measures of

this test (Deaton, 1997; see also Burgess and Zhuang 2000 for negative results in a region of China with strong son preference). It may be that nutrition is not the mechanism through which son preference is expressed. 
virilocality. For example, results for tables 3 to 6 are similar when we disaggregate birth cohorts more finely. In the tables and regressions we presented results using the definition of "virilocal" communities as reported by the adat expert. We replicated all results using three additional methods: (1) looking at communities with over 75 percent virilocal behavior; (2) defining at the individual level whether the parents in the household had followed virilocal norms; and (3) grouping communities into ethnic groups, and using the average virilocal or uxorilocal tradition of the ethnic group to code the community.

Alternative cuts of households and communities did not change the basic story.

\section{Conclusions and recommendations for further research}

Evidence from the Indonesia Family Life Survey finds no strong correlation between virilocality and differential investments in or treatment of daughters. On the one hand, regions with virilocal norms were more likely than other regions to report other norms that disadvantaged their daughters. On the other hand, virilocal regions did not have "missing daughters," nor patterns of rapid attempts to have another child after the birth of a daughter, nor relatively lower levels of education of women, nor relatively low height for age for women, relative to uxorilocal or ambilocal regions. The evidence we and others have found against strong son preference in Indonesia does not seem to be a statistical artifact of averaging over a large country with much diversity.

Many scholars have argued convincingly that there is a causal relationship between virilocality and son preference. The evidence from Indonesia casts doubt on these assertions. A suggestive study using district-level data from India by Malhotra, Vanneman and Kishor, 1995, also finds that a proxy for movement at marriage under virilocality is not related to fertility outcomes. At the same time, it is possible that the received wisdom applies in those nations, even if not in Indonesia, because virilocality there is coupled with other norms that harm women. There have been efforts to identify cultural complexes within India, as explanation for differential outcomes by sex (Dyson and Moore 1983). The clustering of patriarchal norms does not seem to be very tight in Indonesia. It could be the combination of norms that include, but are not restricted to, virilocality, reduces investments in daughters. Moreover, 
daughters in virilocal regions may retain more contact with their parents in Indonesia than in most of India or China.

For that reason, arguments about the effects of virilocality should be complemented by examination of the marriage market and norms regarding care of parents, and should be confirmed by looking more intensively at border areas where there is variation in norms of post-marital residence. Recent studies are indeed beginning to shed more light on the link between virilocality, son preference, marriage markets, and other aspects of economy and society. Burgess and Zhuang (2001) argue that census-level data from two provinces in China suggests that son preference diminishes with rising per capita income. Anderson (2000) develops a model explaining differences in dowry payments across societies. Zhang and Chan(1999) and Hallman (2000) use unique datasets from Taiwan and Bangladesh, respectively, to unpack some of the differential effects of marriage payments on subsequent marriage outcomes.

Further research is needed to shed light on the importance of transfers from the groom's family that reward investments in daughters, the role of altruism, and potential economic or non-economic forces that raise the relative status of women in Indonesia and other regions in Southeast Asia relative to much of South and East Asia. 


\section{References}

Adam, Leonhard. "Virilocal and Uxorilocal." American Anthropologist 49 (1947): 678.

Agarwal, Bina. A field of one's own : gender and land rights in South Asia Cambridge South Asian studies. Cambridge England ; New York, NY, USA: Cambridge University Press, 1994.

Anderson, Siwan. The economics of dowry payments in Pakistan. : CentER Discussion Papers, Tilburg University, 2000.

Atkinson, Jane Monnig, and Shelly Errington. Power and Difference: Gender in Island Southeast Asia . Stanford: Stanford University Press, 1990.

Bardhan, Kalpana, and S. Klasen. "Women's welfare and gender equity in emerging Asia." Asian Development Review (1999).

Barnes, R.H. "Marriage, Exchange and the Meaning of marriage Corporations in Eastern Indonesia." In The Meaning of Marriage Payments, ed. J.L. Comaroff. London: Academic Press, 1980.

Blackwood, E. "Women, land, and labor: Negotiating clientage and kinship in a Minangkabau peasant community." Ethnology 36, no. 4 (1997): 277-293.

Bloom, Shelah S., David Wypij, and Monica Das Gupta. "Dimensions of Women's Autonomy and the Influence on Maternal Health Care Utilization in a North Indian City." Demography 38, no. 1 (2001): 67-78.

Burgess, Robin, and Juzhong Zhuang. Modernisation and Son Preference. : London School of Economics, 2001.

Cameron, L., and C. Worswick. "Education Expenditure Responses to Crop Loss in Indonesia: A Gender Bias." Economic Development and Cultural Change 49, no. 2 (2000): 351-.

Dube, Leela. Women and Kinship: Comparative Perspectives on Gender in South and South-East Asia. Tokyo: United Nations University Press, 1997.

Dyson, Tim, and Mick Moore. "On Kinship Structure, Female Autonomy, and Demographic Behavior in India." Population and Development Review 9, no. 1 (1983): 35-60.

Errington, Shelly. "Recasting Sex, Gender, and Power: A Theoretical and Regional Overview." In Power and Difference: Gender in Island Southeast Asia, ed. Jane Atkinson and Shelly Errington, 1-58. Stanford: Stanford University Press, 1990.

Frankenberg, E., L. Karoly, P. Gertler, C. Peterson, and Wesley D. The 1993 Indonesian Family Life Survey: Overview and Field Report. Santa Monica, CA: RAND, 1995, DRU-1195.

Garg, Ashish, and Jonathan Morduch. "Sibling rivalry and the gender gap: Evidence from child health outcomes in Ghana." Journal of Population Economics 11 (1998): 471-93.

Guest, Philip. "Marital Dissolution and Development in Indonesia." Journal of Comparative Family Studies 23, no. 1 (1992): 95-113. 
Hallman, Kelly. Mother-Daughter Resource Control, Marriage Payments, and Girl-Boy Health in Rural Bangladesh. Washington, DC: IFPRI, 2000.

Ihromi, T. Omas. "Inheritance and Equal Rights for Toba Batak Daughters." Law \& Society Review 28, no. 4 (1994): 525-38.

Jeffery, Patricia, Roger Jeffery, and Andrew Lyon. "When Did You last See Your Mother? Aspects of Female Autonomy in Rural North India." In Micro-Approaches to Demographic Research, ed. John Caldwell, Allan Hill, and Valerie Hull, 321-333. London: Kegan Paul, 1988.

Jones, Gavin W. Marriage and divorce in Islamic South-East Asia South-East Asian social science monographs. Kuala Lumpur ; New York: Oxford University Press, 1994.

Karim, Wazir Jahan. "Introduction: Genderising Anthropology in Southeast Asia." In 'Male' and 'Female' in Developing Southeast Asia, ed. Wazir Jahan Karim, 11-34. Oxford: Berg Publishers, 1995.

Kevane, Michael, and David Levine. The Changing Status of Daughters in Indonesia . : Haas School of Business, University of California at Berkeley, 2001.

Libbee, M.J., and D.E. Sopher. "Marriage Migration in Rural India." In People on the Move: Studies on Internal Migration, ed. Leszek Kosinski and R. Mansell Prothero, 347-59. London: Methuen \& CO. Ltd., 1975.

Parker, L. "Engendering school children in Bali." Journal of the Royal Anthropological Institute 3, no. 3 (1997): 497-516.

Rosenzweig, M., and K. Wolpin. "Specific Experience, Household Structure, and Intergenerational Transfers: Farm Family Land and Labor Arrangements in Developing Countries." Quarterly Journal of Economics 100 (1985): 961-988.

Rosenzweig, M. R., and O. Stark. "Consumption Smoothing, Migration, and Marriage - Evidence From Rural India." Journal of Political Economy 97, no. 4 (1989): 905-926.

Skinner, G. William. "Family Systems and Demographic Processes." In Anthropological Demography: Toward a New Synthesis, ed. David Kertzer and Tom Fricke, 53-114. Chicago: University of Chicago Press, 1997.

Stoler, Ann. "Class Structure and Female Autonomy in Rural Java." Signs 3 (1977): 74-89.

Thomas, Duncan, Elizabeth Frankenberg, Kathleen Beegle, and Graciela Teruel. Household budgets, household composition and the crisis in Indonesia: Evidence from longitudinal household survey data. : RAND, 1999.

Warren, Carol. Adat and dinas : Balinese communities in the Indonesian state South-East Asian social science monographs. Kuala Lumpur ; New York: Oxford University Press, 1995.

Wazir-Jahan Begum, Karim. "Male" and "female" in developing Southeast Asia. Oxford ; Washington, D.C., USA: Berg Publishers, 1995. 
Zhang, J. S., and W. Chan. "Dowry and wife's welfare: A theoretical and empirical analysis." Journal of Political Economy 107, no. 4 (1999): 786-808. 
Table 1: Marriage residence patterns and adat norm adat according to expert

percent of uxorilocal virilocal ambilocal

actual marriages

of indicated type

virilocal

$27 \% \quad 68 \% \quad 34 \%$

uxorilocal

60

20

49

ambilocal

09

10

12

$\mathrm{n}=1506 \quad \mathrm{n}=713 \quad \mathrm{n}=881$

Note: Sample is all women married after 1970 in areas where adat experts responded, using 1997 IFLS. Marriages before 1970 had similar patterns. Virilocal marriages have the bride coming to the husband, uxorilocal have the husband coming to the bride's home, and ambilocal refers to marriages with residence with neither set of parents. 
Table 2: Percent of adat experts responding positively to questions related to gender of children

\begin{tabular}{|c|c|c|c|}
\hline & uxorilocal & virilocal & ambilocal \\
\hline want male child for first child? & 0.47 & 0.60 & $0.41 \star$ \\
\hline pressure to have a male child? & 0.42 & 0.45 & $0.27 *$ \\
\hline no pressure to have female child? & $0.70 * \star$ & 0.88 & 0.78 \\
\hline husband might remarry if no male child? & 0.07 & 0.08 & 0.10 \\
\hline if adopt, boys more likely to be adopted? & 0.00 & 0.03 & 0.11 \\
\hline boys given education priority? & $0.59 * \star$ & 0.30 & 0.46 \\
\hline boys given health care priority? & $0.02 \star \star$ & 0.10 & 0.08 \\
\hline boys receive more than $50 \%$ of inheritance? & $0.65 \star \star$ & 0.87 & $0.60 * \star$ \\
\hline parents live with daughter? & $0.48 * \star$ & 0.12 & $0.44 * \star$ \\
\hline & $\mathrm{n}=132$ & $\mathrm{n}=60$ & $\mathrm{n}=78$ \\
\hline
\end{tabular}


Table 3: Sex ratios of children alive and children who died according to post-marital residence norm

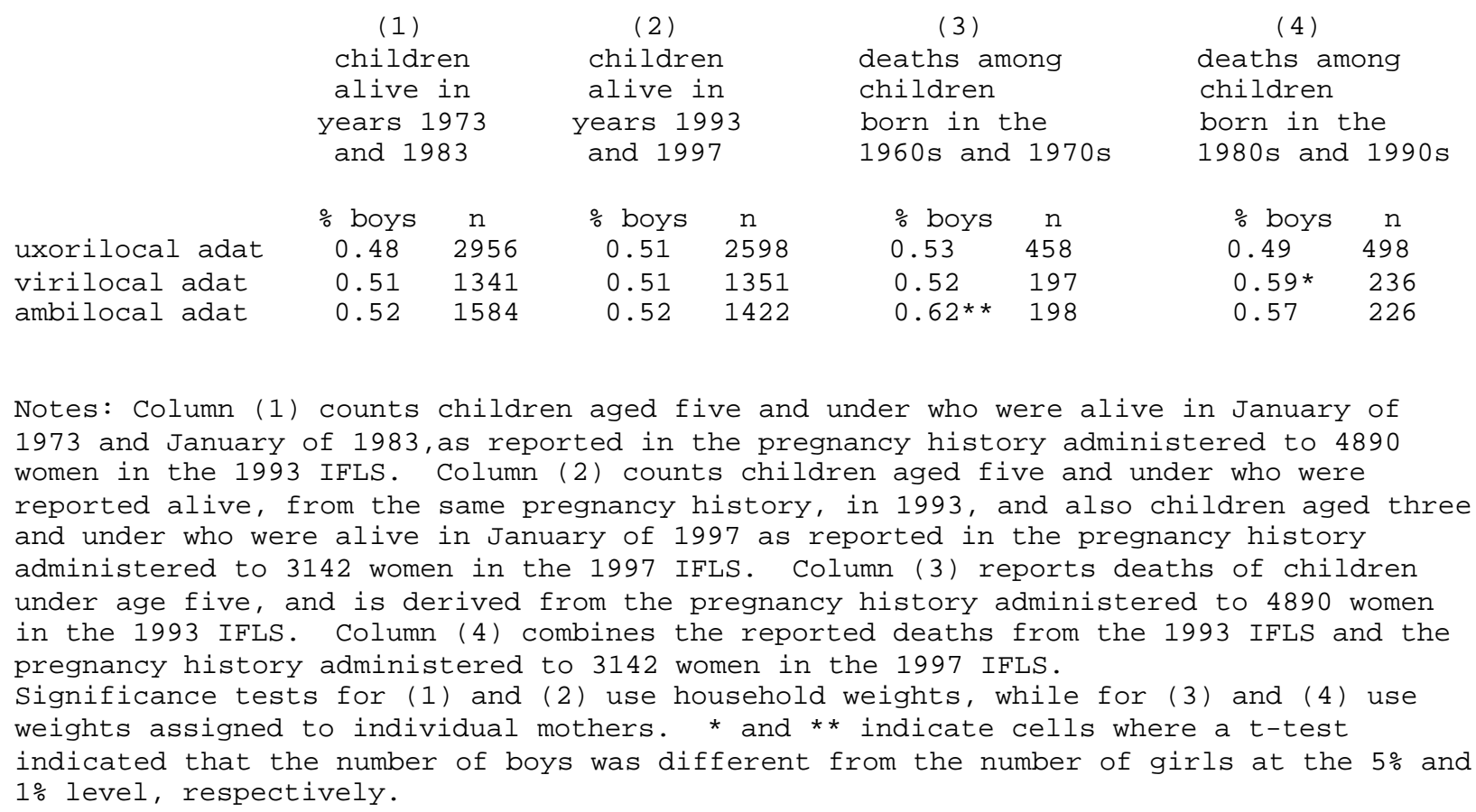


Table 4: Are youngest children more often boys in virilocal areas?

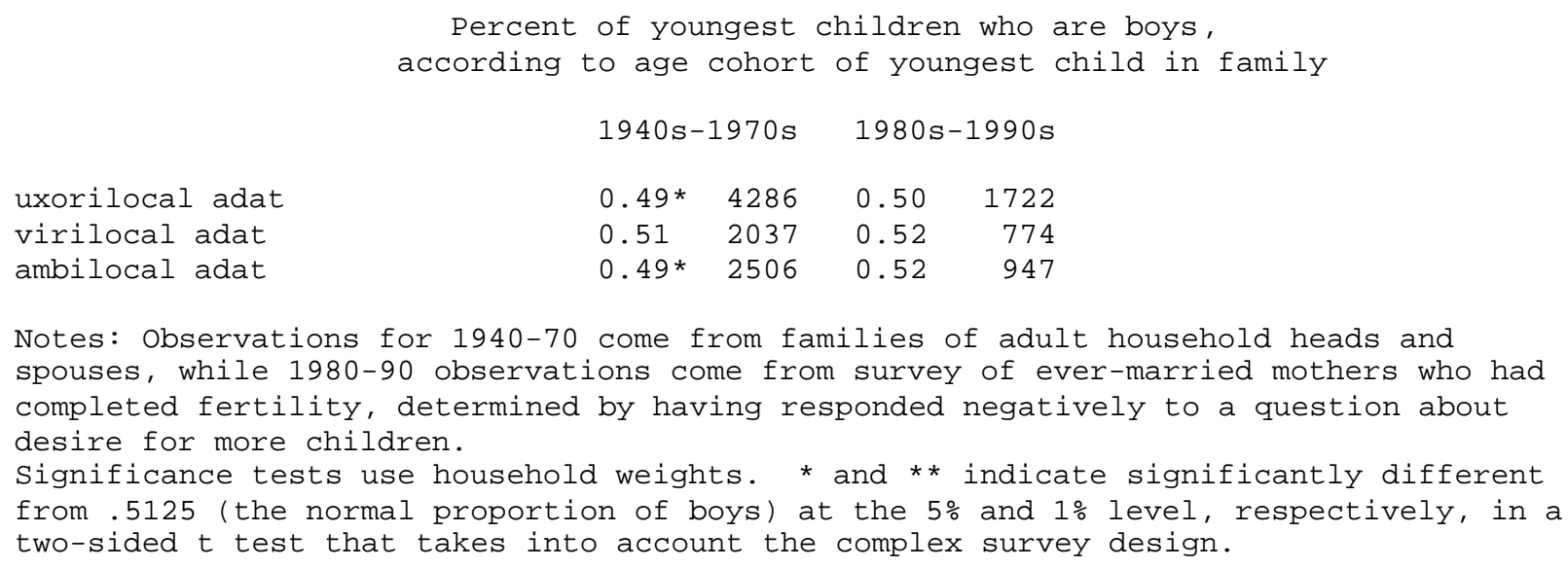


Table 5: Do girls live in bigger families in virilocal areas?

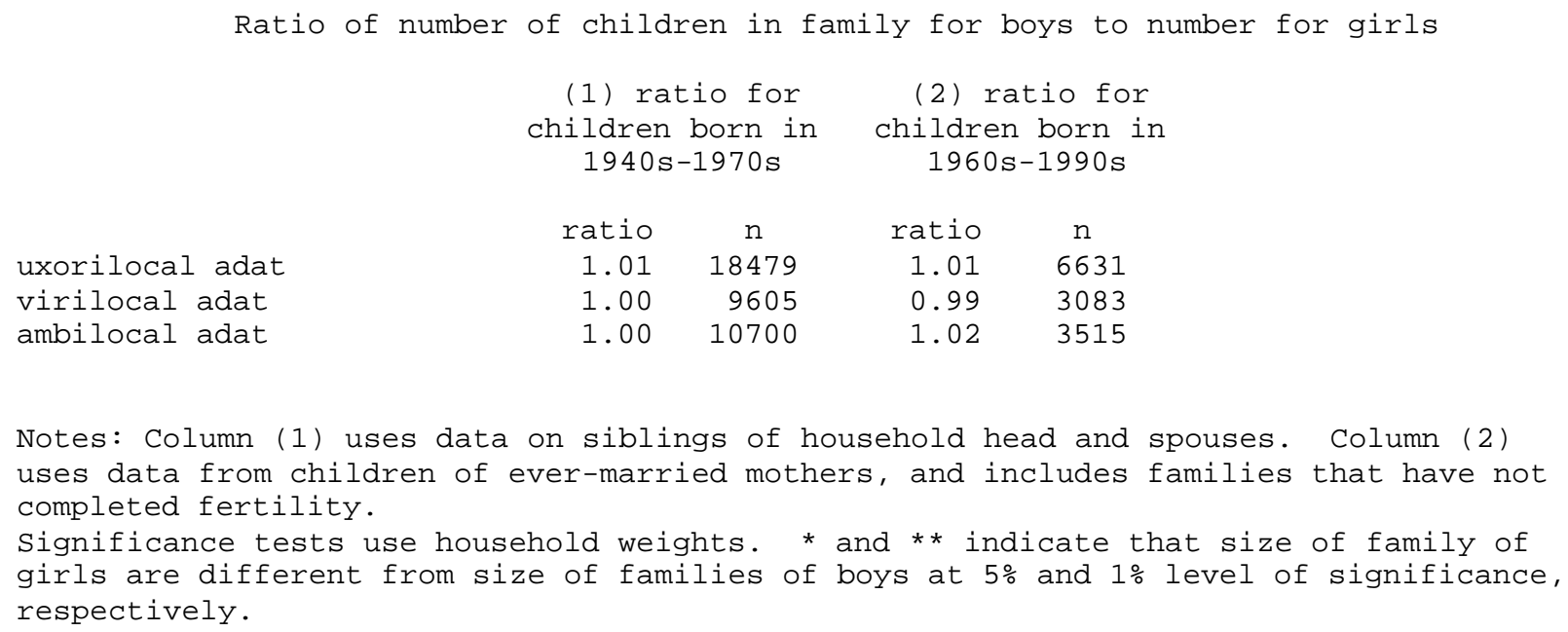


Table 6: After a boy, do parents wait longer to have another child in virilocal areas?

Ratio of mean interval, in years, until next child following birth of a son to years following birth of a daughter

(1)

siblings of

adults, born 1940s-

$1970 \mathrm{~s}$

ratio $\quad \mathrm{n}$

$1.02 \quad 12162$

1.046540

$1.05 * 7108$
(2)

children of ever-

married women, born 1970s-1990s

ratio $n$

$0.99 \quad 3767$

0.94 * 1831

$0.99 \quad 1956$

ambilocal adat

Notes: Column (1) uses sample of families of adult heads of households and spouses of heads, Column (2) uses sample of children of ever-married mothers, from pregnancy history administered to 4890 women in the 1993 IFLS, excluding intervals where the previously born child died prior to conception of the next child. Intervals calculated using year of birth for column (1), and year and month of birth for column (2). If interval less than .66, or zero, or greater than 15, then excluded.

Significance tests use household weights. * and ** indicate that interval till the next child following birth of a boy is significantly different from the interval following a girl, at the 5\% and 1\% level, respectively using a Wald test for differences in means that takes into account complex survey design. 
Table 7: Are Girls and Women Shorter and Less Educated in Virilocal Regions?

\begin{tabular}{|c|c|c|c|c|}
\hline & \multicolumn{4}{|c|}{ Virilocality measured by adat } \\
\hline & \multicolumn{2}{|c|}{ Sample: Children } & \multicolumn{2}{|c|}{ Sample: Adults } \\
\hline & (1) & $(2)$ & (3) & $(4)$ \\
\hline & $z$-scored & years of & height in & years of \\
\hline & height & schooling & $\mathrm{cm}$ & schooling \\
\hline Female & 0.050 & -0.062 & -11.760 & -2.419 \\
\hline & $(0.24)$ & $(0.30)$ & $(16.67) \star \star$ & $(6.89) \star \star$ \\
\hline virilocal area & -0.184 & -0.205 & -1.393 & 0.116 \\
\hline & $(1.25)$ & $(1.12)$ & $(1.92)$ & $(0.27)$ \\
\hline virilocal area * female & $\begin{array}{l}0.006 \\
(0.03)\end{array}$ & $\begin{array}{l}0.053 \\
(0.25)\end{array}$ & $\begin{array}{r}-0.406 \\
(0.45)\end{array}$ & $\begin{array}{l}0.264 \\
(0.66)\end{array}$ \\
\hline uxorilocal area & $\begin{array}{l}-0.046 \\
(0.37)\end{array}$ & $\begin{array}{l}-0.249 \\
(2.05) \star\end{array}$ & $\begin{array}{l}-0.845 \\
(1.46)\end{array}$ & $\begin{array}{l}-0.797 \\
(2.45) \star\end{array}$ \\
\hline uxorilocal area * female & 0.115 & 0.263 & 0.018 & 0.686 \\
\hline & $(0.73)$ & $(1.68)$ & $(0.03)$ & $(2.27) *$ \\
\hline age in years & -0.347 & 1.072 & 0.165 & -0.066 \\
\hline & $(8.08) * *$ & $(25.79) \star \star$ & $(1.80)$ & $(1.26)$ \\
\hline age squared & 0.028 & -0.018 & -0.003 & -0.000 \\
\hline & $(7.03) \star \star$ & $(9.62) \star \star$ & $(2.79) \star \star$ & $(0.21)$ \\
\hline number of siblings & -0.055 & -0.062 & 0.094 & 0.269 \\
\hline & $(3.04) * \star$ & $(2.81) \star \star$ & $(2.25) \star$ & $(10.88) * \star$ \\
\hline are you only child? & $\begin{array}{l}-0.068 \\
(0.79)\end{array}$ & $\begin{array}{l}-0.083 \\
(0.91)\end{array}$ & $\begin{array}{r}-0.142 \\
(0.45)\end{array}$ & $\begin{array}{r}0.072 \\
(0.41)\end{array}$ \\
\hline \% siblings who are brothers & $\begin{array}{l}0.116 \\
(0.59)\end{array}$ & $\begin{array}{l}-0.296 \\
(2.12) *\end{array}$ & $\begin{array}{l}-0.813 \\
(1.33)\end{array}$ & $\begin{array}{l}-0.941 \\
(2.95) * \star\end{array}$ \\
\hline \% siblings brothers*female & -0.014 & 0.417 & 0.457 & 0.971 \\
\hline & $(0.05)$ & $(2.01) *$ & $(0.54)$ & $(2.62) * \star$ \\
\hline virilocal*\% brothers & -0.415 & 0.454 & 0.488 & 0.472 \\
\hline & $(1.29)$ & $(1.98) \star$ & $(0.47)$ & $(0.85)$ \\
\hline uxorilocal*\% brothers & -0.088 & 0.202 & 0.482 & 1.026 \\
\hline & $(0.37)$ & $(1.13)$ & $(0.56)$ & $(2.46) *$ \\
\hline virilocal*female*\% brothers & $\begin{array}{r}0.201 \\
(0.55)\end{array}$ & $\begin{array}{l}-0.538 \\
(1.80)\end{array}$ & $\begin{array}{r}1.112 \\
(0.77)\end{array}$ & $\begin{array}{l}-0.366 \\
(0.54)\end{array}$ \\
\hline uxorilocal*female*\% brothers & $\begin{array}{c}0.034 \\
(0.11)\end{array}$ & $\begin{array}{l}-0.436 \\
(1.65)\end{array}$ & $\begin{array}{l}-0.282 \\
(0.24)\end{array}$ & $\begin{array}{l}-0.986 \\
(1.84)\end{array}$ \\
\hline Muslim & -0.244 & -0.127 & -1.798 & -1.075 \\
\hline & $(1.73)$ & $(0.92)$ & $(3.23) \star \star$ & $(2.87) \star \star$ \\
\hline Muslim*female & 0.069 & -0.150 & 0.395 & 0.186 \\
\hline & $(0.38)$ & $(0.85)$ & $(0.70)$ & $(0.66)$ \\
\hline urban area & 0.430 & 0.898 & 1.080 & 2.849 \\
\hline & $(5.82) * \star$ & $(10.64) * \star$ & $(4.56) \star \star$ & $(11.76) \star \star$ \\
\hline Constant & $\begin{array}{l}-0.759 \\
(3.91) \star \star\end{array}$ & $\begin{array}{l}-5.592 \\
(20.00) \star \star\end{array}$ & $\begin{array}{l}160.956 \\
(81.63) \star \star\end{array}$ & $\begin{array}{c}8.379 \\
(7.24) \star \star\end{array}$ \\
\hline Test that viri*girl=uxori*girl & $F(1,317)=0.36$ & $F(1,319)=1.06$ & $\begin{array}{c}F(1,384)=0.2 \\
4\end{array}$ & $F(1,388)=1.24$ \\
\hline $\begin{array}{l}\text { Test that \% bros*viri*girl }=\frac{\circ}{0} \\
\text { bros.*uxori*girl }\end{array}$ & $F(1,317)=0.27$ & $F(1,319)=0.14$ & $\begin{array}{c}F(1,384)=0.9 \\
5\end{array}$ & $F(1,388)=0.82$ \\
\hline Observations & 5796 & 10402 & 7477 & 7766 \\
\hline R-squared & 0.05 & 0.66 & 0.49 & 0.24 \\
\hline
\end{tabular}


Table 8: Do Families with Daughters Spend More on Adult Goods or Less on Food in Virilocal Regions?

\begin{tabular}{|c|c|c|c|c|c|c|}
\hline & \multicolumn{2}{|c|}{$\begin{array}{c}\text { All dependent variables first- } \\
\text { differenced }\end{array}$} \\
\hline & (1) & (2) & (3) & $(4)$ & $(5)$ & $(6)$ \\
\hline & $\begin{array}{l}\text { share of food } \\
\text { items } 1993\end{array}$ & $\begin{array}{l}\text { share of adult } \\
\text { goods } 1993\end{array}$ & $\begin{array}{l}\text { share of food } \\
\text { items } 1997\end{array}$ & $\begin{array}{c}\text { share of } \\
\text { adult goods } \\
1997\end{array}$ & $\begin{array}{c}\text { change in share } \\
\text { of food items } \\
1993-97\end{array}$ & $\begin{array}{c}\text { change in share } \\
\text { of adult goods } \\
1993-97\end{array}$ \\
\hline girls 0 to 4 & $\begin{array}{l}0.016 \\
(2.57) \star\end{array}$ & $\begin{array}{l}-0.005 \\
(1.64)\end{array}$ & $\begin{array}{l}0.019 \\
(2.76) * *\end{array}$ & $\begin{array}{r}0.000 \\
(0.07)\end{array}$ & $\begin{array}{r}0.006 \\
(0.86)\end{array}$ & $\begin{array}{l}-0.007 \\
(2.26)^{\star}\end{array}$ \\
\hline boys 0 to 4 & $\begin{array}{l}0.018 \\
(2.56)^{*}\end{array}$ & $\begin{array}{l}-0.005 \\
(2.12) *\end{array}$ & $\begin{array}{l}0.013 \\
(2.11)^{\star}\end{array}$ & $\begin{array}{l}-0.003 \\
(0.96)\end{array}$ & $\begin{array}{r}0.004 \\
(0.46)\end{array}$ & $\begin{array}{l}-0.013 \\
(3.66) * *\end{array}$ \\
\hline girls 5 to 9 & $\begin{array}{r}0.012 \\
(1.74)\end{array}$ & $\begin{array}{l}-0.009 \\
(3.64) * *\end{array}$ & $\begin{array}{l}0.021 \\
(3.57) * *\end{array}$ & $\begin{array}{l}-0.003 \\
(1.00)\end{array}$ & $\begin{array}{r}0.001 \\
(0.15)\end{array}$ & $\begin{array}{l}-0.007 \\
(2.18)^{\star}\end{array}$ \\
\hline boys 5 to 9 & 0.016 & -0.005 & 0.019 & -0.002 & -0.008 & -0.009 \\
\hline girls 10 to 14 & $\begin{array}{l}(3.20) * * \\
-0.013 \\
(2.47) *\end{array}$ & $\begin{array}{l}(1.86) \\
-0.005 \\
(2.22) \star\end{array}$ & $\begin{array}{l}(2.77) * * \\
0.014 \\
(2.64) * \star\end{array}$ & $\begin{array}{l}(0.66) \\
-0.005 \\
(2.21) *\end{array}$ & $\begin{array}{r}(1.13) \\
0.004 \\
(0.47)\end{array}$ & $\begin{array}{l}(2.30)^{\star} \\
0.000 \\
(0.06)\end{array}$ \\
\hline boys 10 to 14 & 0.002 & -0.010 & 0.011 & 0.000 & -0.007 & -0.006 \\
\hline girls 15 to 19 & $\begin{array}{r}(0.36) \\
-0.002\end{array}$ & $\begin{array}{l}(4.86) * \star \\
-0.004\end{array}$ & $\begin{array}{l}(2.05)^{*} \\
0.000\end{array}$ & $\begin{array}{l}(0.05) \\
-0.007\end{array}$ & $\begin{array}{r}(1.07) \\
0.008\end{array}$ & $\begin{array}{r}(1.87) \\
-0.000\end{array}$ \\
\hline & $(0.36)$ & $(1.62)$ & $(0.06)$ & $(2.44) *$ & $(1.14)$ & $(0.01)$ \\
\hline boys 15 to 19 & $\begin{array}{l}0.002 \\
(0.39)\end{array}$ & $\begin{array}{l}-0.010 \\
(3.90) * *\end{array}$ & $\begin{array}{l}0.016 \\
(2.69) * *\end{array}$ & $\begin{array}{r}0.000 \\
(0.02)\end{array}$ & $\begin{array}{r}0.002 \\
(0.28)\end{array}$ & $\begin{array}{r}-0.002 \\
(0.53)\end{array}$ \\
\hline women 20 to 29 & $\begin{array}{l}0.010 \\
(1.56)\end{array}$ & $\begin{array}{l}0.000 \\
(0.10)\end{array}$ & $\begin{array}{c}-0.005 \\
(0.77)\end{array}$ & $\begin{array}{l}-0.006 \\
(2.07)^{\star}\end{array}$ & $\begin{array}{r}-0.001 \\
(0.10)\end{array}$ & $\begin{array}{l}-0.001 \\
(0.23)\end{array}$ \\
\hline men 20 to 29 & $\begin{array}{r}0.009 \\
(1.37)\end{array}$ & $\begin{array}{l}0.009 \\
(3.19) * *\end{array}$ & $\begin{array}{r}0.007 \\
(1.12)\end{array}$ & $\begin{array}{l}0.012 \\
(4.04) * *\end{array}$ & $\begin{array}{r}0.000 \\
(0.03)\end{array}$ & $\begin{array}{l}0.017 \\
(5.08) * \star\end{array}$ \\
\hline women 30 to 54 & 0.021 & -0.004 & 0.015 & -0.006 & 0.014 & -0.007 \\
\hline men 30 to 54 & $\begin{array}{l}(3.00) \star \star \\
-0.004\end{array}$ & $\begin{array}{r}(1.33) \\
0.017\end{array}$ & $\begin{array}{l}(2.01)^{\star} \\
-0.015\end{array}$ & $\begin{array}{r}(1.84) \\
0.016\end{array}$ & $\begin{array}{l}(1.63) \\
-0.006\end{array}$ & $\begin{array}{r}(1.64) \\
0.021\end{array}$ \\
\hline women 55 or over & $\begin{array}{r}(0.48) \\
0.010 \\
(1.43)\end{array}$ & $\begin{array}{l}(3.84) * \star \\
-0.005 \\
(1.29)\end{array}$ & $\begin{array}{c}(1.92) \\
0.003 \\
(0.39)\end{array}$ & $\begin{array}{l}(3.64) * * \\
0.000 \\
(0.10)\end{array}$ & $\begin{array}{r}(0.66) \\
0.025 \\
(1.95)\end{array}$ & $\begin{array}{l}(4.42) * * \\
-0.008 \\
(1.36)\end{array}$ \\
\hline men 55 or over & $\begin{array}{l}-0.006 \\
(0.55)\end{array}$ & $\begin{array}{c}0.003 \\
(0.75)\end{array}$ & $\begin{array}{c}0.002 \\
(0.24)\end{array}$ & $\begin{array}{r}0.007 \\
(1.80)\end{array}$ & $\begin{array}{r}-0.002 \\
(0.17)\end{array}$ & $\begin{array}{c}0.014 \\
(2.19) *\end{array}$ \\
\hline girls 0 to $4^{*}$ viri adat & $\begin{array}{c}-0.002 \\
(0.14)\end{array}$ & $\begin{array}{r}0.002 \\
(0.31)\end{array}$ & $\begin{array}{r}0.010 \\
(0.60)\end{array}$ & $\begin{array}{l}0.005 \\
(0.70)\end{array}$ & $\begin{array}{r}-0.001 \\
(0.08)\end{array}$ & $\begin{array}{c}-0.001 \\
(0.23)\end{array}$ \\
\hline boys 0 to $4^{*}$ viri adat & $\begin{array}{l}0.027 \\
(2.03) *\end{array}$ & $\begin{array}{l}-0.001 \\
(0.19)\end{array}$ & $\begin{array}{c}0.004 \\
(0.27)\end{array}$ & $\begin{array}{l}0.003 \\
(0.63)\end{array}$ & $\begin{array}{r}0.001 \\
(0.09)\end{array}$ & $\begin{array}{l}0.006 \\
(0.72)\end{array}$ \\
\hline girls 5 to 9*viri adat & -0.022 & 0.009 & -0.018 & 0.001 & -0.008 & 0.005 \\
\hline & $(1.67)$ & $(1.85)$ & $(1.21)$ & $(0.16)$ & $(0.55)$ & $(0.69)$ \\
\hline boys 5 to $9{ }^{*}$ viri adat & -0.025 & 0.007 & 0.024 & -0.001 & 0.020 & 0.007 \\
\hline & $(2.33) *$ & $(1.49)$ & $(1.80)$ & $(0.13)$ & $(1.27)$ & $(1.04)$ \\
\hline girls 10 to $14 * v i r i$ adat & 0.008 & 0.004 & -0.012 & 0.006 & -0.004 & -0.003 \\
\hline boys 10 to $14^{*}$ viri adat & $\begin{array}{r}(0.64) \\
0.014\end{array}$ & $\begin{array}{l}(0.81) \\
-0.000\end{array}$ & $\begin{array}{r}(0.98) \\
0.005\end{array}$ & $\begin{array}{r}(1.12) \\
0.001\end{array}$ & $\begin{array}{r}(0.26) \\
0.030\end{array}$ & $\begin{array}{r}(0.54) \\
-0.002\end{array}$ \\
\hline & $(1.52)$ & $(0.10)$ & $(0.44)$ & $(0.09)$ & $(1.64)$ & $(0.31)$ \\
\hline girls 15 to $19 *$ viri adat & $\begin{array}{c}-0.005 \\
(0.43)\end{array}$ & $\begin{array}{l}0.004 \\
(0.64)\end{array}$ & $\begin{array}{r}0.017 \\
(1.09)\end{array}$ & $\begin{array}{c}-0.002 \\
(0.34)\end{array}$ & $\begin{array}{l}-0.006 \\
(0.33)\end{array}$ & $\begin{array}{c}-0.008 \\
(1.08)\end{array}$ \\
\hline boys 15 to $19 * v i r i$ adat & $\begin{array}{c}0.004 \\
(0.34)\end{array}$ & $\begin{array}{l}-0.005 \\
(1.03)\end{array}$ & $\begin{array}{c}-0.002 \\
(0.13)\end{array}$ & $\begin{array}{l}-0.008 \\
(1.70)\end{array}$ & $\begin{array}{r}0.005 \\
(0.30)\end{array}$ & $\begin{array}{r}0.000 \\
(0.00)\end{array}$ \\
\hline women 20 to $29 *$ viri adat & $\begin{array}{r}-0.001 \\
(0.11)\end{array}$ & $\begin{array}{r}-0.011 \\
(1.56)\end{array}$ & $\begin{array}{l}0.044 \\
(2.99) * *\end{array}$ & $\begin{array}{l}0.002 \\
(0.32)\end{array}$ & $\begin{array}{c}0.039 \\
(2.39) *\end{array}$ & $\begin{array}{l}-0.015 \\
(1.83)\end{array}$ \\
\hline men 20 to $29{ }^{*}$ viri adat & -0.007 & -0.000 & -0.023 & -0.009 & -0.004 & -0.004 \\
\hline women 30 to $54^{*}$ viri adat & $\begin{array}{r}(0.54) \\
-0.025\end{array}$ & $\begin{array}{l}(0.01) \\
-0.009\end{array}$ & $\begin{array}{r}(1.45) \\
0.009\end{array}$ & $\begin{array}{l}(1.23) \\
-0.006\end{array}$ & $\begin{array}{r}(0.26) \\
0.041\end{array}$ & $\begin{array}{l}(0.49) \\
-0.004\end{array}$ \\
\hline men 30 to $54 *$ viri adat & $\begin{array}{r}(1.61) \\
0.009\end{array}$ & $\begin{array}{l}(1.35) \\
-0.007\end{array}$ & $\begin{array}{l}(0.50) \\
-0.003\end{array}$ & $\begin{array}{r}(1.05) \\
0.002\end{array}$ & $\begin{array}{r}(1.75) \\
-0.032\end{array}$ & $\begin{array}{r}(0.40) \\
0.009\end{array}$ \\
\hline women 55 plus*viri adat & $\begin{array}{r}(0.60) \\
-0.023\end{array}$ & $\begin{array}{r}(1.09) \\
0.004\end{array}$ & $\begin{array}{r}(0.24) \\
-0.007\end{array}$ & $\begin{array}{r}(0.25) \\
0.000\end{array}$ & $\begin{array}{r}(1.56) \\
0.028\end{array}$ & $\begin{array}{r}(0.89) \\
-0.006\end{array}$ \\
\hline & $(1.06)$ & $(0.64)$ & $(0.34)$ & $(0.03)$ & $(1.19)$ & $(0.55)$ \\
\hline men 55 plus*viri adat & $\begin{array}{l}0.038 \\
(1.99) *\end{array}$ & $\begin{array}{l}-0.005 \\
(0.67)\end{array}$ & $\begin{array}{r}0.031 \\
(1.60)\end{array}$ & $\begin{array}{l}-0.016 \\
(2.48)^{\star}\end{array}$ & $\begin{array}{l}0.010 \\
(0.46)\end{array}$ & $\begin{array}{c}-0.008 \\
(0.60)\end{array}$ \\
\hline Female headed household & $\begin{array}{l}0.034 \\
(2.77) * *\end{array}$ & $\begin{array}{l}-0.021 \\
(4.54) * *\end{array}$ & $\begin{array}{l}0.029 \\
(2.68) * *\end{array}$ & $\begin{array}{l}-0.019 \\
(4.01) * *\end{array}$ & & \\
\hline Log of per capita expenditure & $\begin{array}{l}-0.042 \\
(6.90) * *\end{array}$ & $\begin{array}{r}0.001 \\
(0.23)\end{array}$ & $\begin{array}{l}-0.054 \\
(7.04) * \star\end{array}$ & $\begin{array}{l}-0.006 \\
(2.38) \star\end{array}$ & $\begin{array}{l}-0.028 \\
(3.25) * *\end{array}$ & $\begin{array}{l}-0.006 \\
(1.87)\end{array}$ \\
\hline is enumeration area rural? & -0.014 & 0.010 & -0.005 & 0.018 & & \\
\hline virilocal marriage adat (1997) & $\begin{array}{r}(1.55) \\
-0.004\end{array}$ & $\begin{array}{l}(2.24) * \\
0.006\end{array}$ & $\begin{array}{r}(0.47) \\
-0.013\end{array}$ & $\begin{array}{l}(4.47) * \star \\
-0.001\end{array}$ & & \\
\hline uxorilocal marriage adat (1997) & $\begin{array}{l}(0.19) \\
-0.016\end{array}$ & $\begin{array}{r}(0.50) \\
0.002\end{array}$ & $\begin{array}{l}(0.43) \\
-0.007\end{array}$ & $\begin{array}{r}(0.09) \\
0.006\end{array}$ & & \\
\hline & $\begin{array}{r}(1.55) \\
-0.153\end{array}$ & $\begin{array}{r}(0.45) \\
-0.024\end{array}$ & $\begin{array}{r}(0.68) \\
-0.022\end{array}$ & $\begin{array}{r}(1.50) \\
-0.013\end{array}$ & & \\
\hline local price index (1993) & $\begin{array}{l}-0.153 \\
(2.58) *\end{array}$ & $\begin{array}{l}-0.024 \\
(0.98)\end{array}$ & $\begin{array}{l}-0.022 \\
(0.35)\end{array}$ & $\begin{array}{l}-0.013 \\
(0.55)\end{array}$ & & \\
\hline Constant & $\begin{array}{c}0.835 \\
(12.80) * \star\end{array}$ & $\begin{array}{l}0.119 \\
(4.75) * *\end{array}$ & $\begin{array}{c}0.913 \\
(11.72) \star \star\end{array}$ & $\begin{array}{c}0.142 \\
(5.32) \star \star\end{array}$ & $\begin{array}{c}0.079 \\
(11.83) * *\end{array}$ & $\begin{array}{l}-0.000 \\
(0.02)\end{array}$ \\
\hline Observations & 5820 & 5820 & 4996 & 4996 & 5387 & 5387 \\
\hline R-squared & 0.06 & 0.04 & 0.08 & 0.05 & 0.01 & 0.02 \\
\hline
\end{tabular}


Table Al: Ethnic groups and residence patterns after marriage By Enumeration Areas (EA)

\begin{tabular}{|c|c|c|c|c|c|c|c|}
\hline & $\begin{array}{l}\# \text { of EA } \\
\text { with adat } \\
\text { answers }\end{array}$ & $\begin{array}{l}\text { of of EA } \\
\text { virilocal } \\
\text { adat }\end{array}$ & $\begin{array}{l}\text { of of EA } \\
\text { uxorilocal } \\
\text { adat }\end{array}$ & $\begin{array}{l}\text { of of } \\
\text { marriages } \\
\text { virilocal }\end{array}$ & $\begin{array}{l}\text { \% of } \\
\text { marriages } \\
\text { uxorilocal }\end{array}$ & $\begin{array}{l}\text { Predominant } \\
\text { island }\end{array}$ & Comment from LeBar \\
\hline Balinese & 15 & 87 & 0 & 90 & 3 & Bali & $\begin{array}{l}\text { Residence after marriage is virilocal, and } \\
\text { usually in the houseyard of the man's parents... } \\
\text { [preferred marriage is with father's brother's } \\
\text { daughter] (pp.62-3) }\end{array}$ \\
\hline Banjar & 9 & 0 & 89 & 28 & 59 & Kalimantan & $\begin{array}{l}\text { Banjar is major city in Dayak/Ibon area; LeBar } \\
\text { does not give information about locality }\end{array}$ \\
\hline Batak & 10 & 80 & 20 & 50 & 23 & Sumatra & $\begin{array}{l}\text { Normally patrilocal, although temporary bride } \\
\text { service in the home of the girl's father } \\
\text { occurs in cases where the full bride-price } \\
\text { cannot be met... The [maximal lineage] is } \\
\text { theoretically exogamous... (p. 21) }\end{array}$ \\
\hline Bugis & 9 & 11 & 78 & 17 & 65 & Sulawesi & $\begin{array}{l}\text {...membership in localized nonunilineal } \\
\text { corporate descent groups through either his } \\
\text { father or mother... ultimate membership is by } \\
\text { choice. (p. 144) }\end{array}$ \\
\hline $\begin{array}{l}\text { Java }+ \\
\text { Betawi }\end{array}$ & 125 & 14 & 48 & 36 & 49 & Java & $\begin{array}{l}\text { There is no fixed rule of residence } \\
\text { determining where a married couple should live } \\
\text { (p. 50) }\end{array}$ \\
\hline Madura & 9 & 0 & 56 & 26 & 54 & Java & $\begin{array}{l}\text { Although the ideal is an independent neolocal } \\
\text { household after marriage, many young couples } \\
\text { stay at the wife's parents' house for the } \\
\text { initial period of married life. One of the } \\
\text { daughters, moreover, remains permanently, with } \\
\text { the obligation to care for the parents in } \\
\text { their old age. (p. 53) }\end{array}$ \\
\hline Minang & 15 & 0 & 100 & 17 & 64 & Sumatra & $\begin{array}{l}\text { Matrilocal in the village with the husband } \\
\text { residing with his wife's matrilineally } \\
\text { extended family...Value is placed on village } \\
\text { endogamy, and a majority of marriages are } \\
\text { within the village.(p. } 25 \text { ) }\end{array}$ \\
\hline Sasak & 10 & 100 & 0 & 76 & 9 & Lombok & $\begin{array}{l}\text { Residence is generally neolocal or } \\
\text { ambilocal... (p. 67) }\end{array}$ \\
\hline Sundanese & 42 & 7 & 54 & 22 & 54 & Java & $\begin{array}{l}\text { The ideal is an independent neolocal household } \\
\text { after marriage... (p. 55) }\end{array}$ \\
\hline Other & 26 & 35 & 42 & 41 & 32 & & \\
\hline Mixed & 26 & n.a. & n.a. & 33 & 67 & & \\
\hline All & $\begin{array}{l}270 \mathrm{EA} \\
\text { for adat; } \\
304 \mathrm{EA} \\
\quad \text { for } \\
\text { marriages }\end{array}$ & 22 & 49 & 37 & 45 & & \\
\hline
\end{tabular}

Notes: Ambilocal communities are the omitted category, so that \%virilocal + \%uxorilocal $+\frac{\circ}{\circ}$ amilocal $=100 \%$

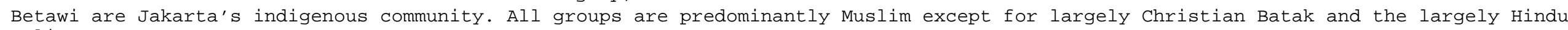
Balinese. 